УДК 332.14

Святогор В.В.

\title{
ОЦІНКА ТА МЕХАНІЗМ СТИМУЛЮВАННЯ ІННОВАЦІЙНОГО РОЗВИТКУ ЗАКАРПАТСЬКОЇ ОБЛАСТІ
}

\begin{abstract}
У статті здійснено аналіз інноваційного розвитку Закарпатської області. Розглянуто й оцінено динаміку та структуру фінансування наукової і науково-технічної діяльності області. Виокремлено та здійснено аналіз основних показників інноваційної діяльності промисловості регіону. Названо та охарактеризовано елементи інноваџійної інфраструктури області. Запропоновано периочергові заходи Закарпатської обласної державної адміністрації для стимулювання інноваційної складової області.
\end{abstract}

Ключові слова: інновації, науково-технічна діяльність, промисловість, інновачійна діяльність, інфраструктура.

Постановка проблеми. Інноваційна активність на регіональному рівні є фактором підвищення конкурентоспроможності території, умовою сталого соціально-економічного розвитку. Тому особливої актуальності набувають питання, пов'язані з аналізом наявного стану інноваційного розвитку регіону, елементами його інноваційної інфраструктури та механізмом стимулювання інноваційного розвитку 3 боку місцевих органів виконавчої влади.

Аналіз останніх досліджень і публікацій. Дослідженню теоретичних та практичних аспектів регіонального інноваційного розвитку присвячені роботи Грицаєнко M.I., Федоренко В.Г., Пилясова А.Н. , Федулова Л.І. та інших вчених.

Аналіз досліджень А. Пілясова та О. Колеснікова показує, що одним з ефективних механізмів інтенсифікації створення i впровадження нових технологій є формування територіальних інноваційних систем або екосистем інновацій. При цьому регіональна політика повинна бути спрямована на виявлення та підтримку територій, що володіють найбільшим потенціалом [15].

М. Грицаєнко стверджує, що інноваційний потенціал регіону - це оптимальне поєднання наявних ресурсів регіону та умов їх раціонального використання для ефективної реалізації інновацій. Виконуючи порівняльний аналіз основних показників, що характеризують інноваційний потенціал України, робить висновок про диспропорції в інноваційному розвитку регіонів [3].

В. Федоренко підкреслює необхідність залучення капіталу в науку та інноваційну

(C) Святогор В'ячеслав Валерійович, здобувач кафедри фінансів і банківської справи ДВНЗ «Ужгородський національний університет», еmail: svv100391@gmail.com діяльність регіону, що забезпечить комплексний розвиток економіки України [4, с. 75].

3 інституціональних позицій до визначення сутності регіонального інноваційного потенціалу, його будови та розвитку підходить Л. Федулова [19].

Вищевикладені трактування вказують на багатовекторність реалізації процесу інноваційного розвитку на рівні регіону, що потребує детальнішого вивчення з метою його подальшого ефективного втілення.

Формулювання цілей статті. Головною метою статті є аналіз інноваційної діяльності та розкриття механізму стимулювання інноваційного розвитку Закарпатської області.

Опис основного матеріалу дослідження. Інноваційний розвиток регіону - це соціальноекономічний процес, в основі якого лежить формування регіональної інноваційної системи. Вона повинна бути здатна до збільшення інноваційного потенціалу регіону та його реалізації шляхом організації високотехнологічних виробництв, заснованих на використанні інтелектуальної праці і продуктів, що створюють високу додану вартість.

У 2015 році в Закарпатській області виконанням наукових та науково-технічний робіт займалося 10 підприємств та організацій області (м. Ужгород - 10, Берегівський район - 1, Рахівський район - 1), у т.ч. 4 - галузевого профілю, 5 - академічного та один вищий навчальний заклад, що на 9,1\% менше, ніж у 2014 році, та більш ніж у двічі порівняно з 2005 роком.

Загальна кількість працівників, які виконували наукові та науково-технічні роботи становила 617 осіб, що на 2,5\% менше, ніж у 2014 році та майже на половину менше зазначеного показника 2005 року. Дана ситуація пов'язана з інтелектуальною міграцією наукових кадрів до країн Європейського Союзу.

Загальний обсяг фінансування внутрішніх витрат на виконання наукових та науково- 
технічних робіт власними силами наукових організацій у 2015 році склав 40278,3 тис. грн., що на $24,5 \%$ більше показника 2014 року та у 2,5 рази більше, ніж у 2005 році. За рахунок державного бюджету, який є основним джерелом фінансування внутрішніх витрат, у 2015 році було здійснено у розмірі 70,1 \%, що переважає відповідний показник по Україні в цілому у 2 рази. Це обумовлено низьким рівнем фінансування витрат за рахунок власних коштів, який у 2015 році склав лише 7,5 \% при значенні у 24,6 \% в Україні. Дана тенденція є незмінною протягом всього аналізованого періоду 2005 2015 pр. (табл. 1).

Таблиця 1

Структура фінансування наукової і науково-технічної діяльності Закарпатської області за джерелами за період 2005 - 2015 рр., тис. грн., \%*

\begin{tabular}{|c|c|c|c|c|c|c|c|c|c|c|c|}
\hline \multirow[b]{2}{*}{ Роки } & \multicolumn{2}{|c|}{$\begin{array}{c}\text { Кошти } \\
\text { державного } \\
\text { бюджету } \\
\end{array}$} & \multicolumn{2}{|c|}{$\begin{array}{c}\text { Позабюджетні } \\
\text { кошти }\end{array}$} & \multicolumn{2}{|c|}{$\begin{array}{c}\text { Кошти } \\
\text { іноземних } \\
\text { джерел } \\
\end{array}$} & \multicolumn{2}{|c|}{ Власні кошти } & \multicolumn{2}{|c|}{$\begin{array}{c}\text { Кошти інших } \\
\text { джерел }\end{array}$} & \multirow{2}{*}{$\begin{array}{c}\text { Всього } \\
\text { Абсолют } \\
\text { - ний } \\
\text { показник } \\
\text { (млн. } \\
\text { грн) }\end{array}$} \\
\hline & $\begin{array}{c}\text { Абсолют } \\
\text { - ний } \\
\text { показник } \\
\text { (млн. } \\
\text { грн) }\end{array}$ & $\begin{array}{c}\text { Віднос } \\
\text {-ний } \\
\text { показ- } \\
\text { ник } \\
(\%)\end{array}$ & $\begin{array}{c}\text { Абсолют } \\
\text { - ний } \\
\text { показник } \\
\text { (млн. } \\
\text { грн) }\end{array}$ & $\begin{array}{c}\text { Віднос } \\
\text {-ний } \\
\text { показ- } \\
\text { ник } \\
(\%)\end{array}$ & $\begin{array}{c}\text { Абсолют } \\
\text { - ний } \\
\text { показник } \\
\text { (млн. } \\
\text { грн) }\end{array}$ & $\begin{array}{c}\text { Віднос } \\
\text {-ний } \\
\text { показ- } \\
\text { ник } \\
(\%)\end{array}$ & $\begin{array}{c}\text { Абсолют } \\
\text { - ний } \\
\text { показник } \\
\text { (млн. } \\
\text { грн) }\end{array}$ & $\begin{array}{c}\text { Віднос } \\
\text {-ний } \\
\text { показ- } \\
\text { ник } \\
(\%)\end{array}$ & $\begin{array}{c}\text { Абсолют } \\
\text { - ний } \\
\text { показник } \\
\text { (млн. } \\
\text { грн) }\end{array}$ & $\begin{array}{c}\text { Віднос } \\
\text {-ний } \\
\text { показ- } \\
\text { ник } \\
(\%)\end{array}$ & \\
\hline 2005 & 11618,9 & 72,0 & 105,1 & 07 & $\mathrm{X}$ & $\mathrm{X}$ & 3222,4 & 19,9 & 1198,3 & 7,4 & 16144,7 \\
\hline 2006 & 14053,8 & 80,6 & 141,3 & 0,8 & 62,9 & 0,4 & 2883,4 & 16,5 & 298,8 & 1,7 & 17440,2 \\
\hline 2007 & 14736,4 & 85,8 & 135,1 & 0,8 & 57,4 & 0,3 & 2011,2 & 11,7 & 240,2 & 1,4 & 17180,3 \\
\hline 2008 & 19985,2 & 86,4 & 168,6 & 0,7 & 56,8 & 0,3 & 2577,7 & 11,1 & 339,9 & 1,5 & 23128,2 \\
\hline 2009 & 18965,2 & 88,6 & 224,1 & 1,1 & 334,1 & 1,5 & 1719,9 & 8,0 & 168,9 & 0,8 & 21412,2 \\
\hline 2010 & 22572,4 & 89,4 & $\mathrm{X}$ & $\mathrm{X}$ & 989,2 & 3,9 & 1210,0 & 4,8 & 482,4 & 1,9 & 25254,0 \\
\hline 2011 & 28792,6 & 91,2 & $\mathrm{X}$ & $\mathrm{X}$ & 532,2 & 1,7 & 1839,2 & 5,8 & 437,2 & 1,4 & 31601,2 \\
\hline 2012 & 32472,4 & 90,9 & $X$ & $\mathrm{X}$ & 309,2 & 0,9 & 2237,4 & 6,3 & 694,6 & 1,9 & 35713,3 \\
\hline 2013 & 33195,2 & 89,6 & $\mathrm{X}$ & $\mathrm{X}$ & 843,8 & 2,3 & 2611,5 & 7,1 & 333,9 & 1,0 & 36984,4 \\
\hline 2014 & 28979,5 & 89,2 & $X$ & $\mathrm{X}$ & 1280,1 & 3,9 & 1946,7 & 6,0 & 280,6 & 0,9 & 32486,9 \\
\hline 2015 & 28340,2 & 70,1 & $X$ & $X$ & $X$ & $\mathrm{X}$ & 3050,0 & 7,5 & 9062,1 & 22,4 & 40452,3 \\
\hline
\end{tabular}

Слід акцентувати увагу і на триваючу уже десятиліттями на Закарпатті ще 3 радянських часів суперечність між вкладами ендогенної складової інноваційного розвитку (власні наукові й інтелектуальні продукти) та екзогенною складовою (придбання і трансфер технологій). За якісними оцінками співвідношення цих вкладів складає приблизно 5:95 - принаймні в оцінках їх розподілу в інноваційній частці продукції промисловості [16].

Кілька інституційно-організаційних та проектно-наукових ініціатив i управлінських рішень, що відбулись впродовж останніх років на Закарпатті, стали прикладами того, що головну суперечність інноваційної діяльності в регіоні (незначну долю ендогенної складової) можна поступово розв'язувати.

Так, у рамках покращення інноваційного середовища та створення ефективної інноваційної інфраструктури в області працює науковий парк „Ужгородський національний університет” (далі - НП „УжНУ”). У рамках реалізації програми НП „УжНУ” здійснюється впровадження
42 інноваційних проектів. Розпочато роботу із наукового проекту за підтримки Міжнародного Вишеградського фонду „Інноваційний університет - інструмент інтеграції в європейський освітній і науковий простір", одним із виконавців якого $є$ НП „УжНУ”.

Крім цього, 30 червня 2017 року у ДВНЗ „УжНУ” відбулося спільне засідання представників українсько-словацького „Меморандуму про співпрацю" (науковців Ужгородського національного та Кошицького технічного університетів), підписаного 20 березня 2017 року в м. Кошице, з питань концепції Проекту формування „Українсько-словацького міжнародного центру інновацій і трансферу технологій" та першочергових практичних кроків по підготовці „дорожньої карти” по формуванню Центру, а також узгоджено спільні дії 3 розробки міжнародної грантової підтримки Проекту.

Сторони Меморандуму повинні підготувати пропозиції для міждержавної підтримки Центру у рамках програми ЕРАЗМУС + , а також грантової підтримки інноваційних проектів по 
пріоритетних напрямах Програми та провести у листопаді спільну конференцію 3 обговорення усіх напрацьованих питань щодо реалізації Проекту створення Українсько-словацького міжнародного центру інновацій i трансферу технологій (Кошице-Ужгород) [14].

Інноваційний потенціал конкурентоспроможності регіональної економіки залежить від інноваційної активності підприємств. Разом 3 тим результати аналізу інноваційної активності підприємств свідчать про гальмування розвитку інноваційного ресурсу. Так, за даними статистичної звітності Закарпатської області, у 2015 році інноваційною діяльністю займались 14 промислових підприємств області, що складає $10,1 \%$ від загальної кількості обстежуваних промислових підприємств, 3 них 42,9 \% розташовано в м. Ужгород, 14,3 \% - у Виноградівському районі. Кількість підприємств, що впроваджували інновації - 13, що майже у 2 рази менше, ніж у 2005 році. Інноваційну продукцію у 2015 році реалізовували 8 промислових підприємств області. Обсяг реалізованої інноваційної продукції склав 583,2 млн. грн., 3 якої 72,8 \% реалізовано за межі України, що майже відповідає відсотковому показнику 2005 року (79,1 \%) та загалом всього досліджуваного періоду 2005 - 2015 рр. Тому можна стверджувати, що область є експортоорієнтованою. У Закарпатській області освоєно виробництво інноваційних видів продукції у 2015 році у кількості 9 одиниць, що складає лише 27,3 \% аналогічного показника 2005 року. У 2015 році освоєно виробництво 16 найменувань інноваційної продукції, що на 24 одиниці менше, ніж у 2005 році. Найбільша їх кількість протягом аналізованого періоду склала 54 одиниці у 2007 році.

Загальний обсяг фінансування інноваційної діяльності протягом 2005 - 2015 рр. мав різну динаміку. Найбільші обсяги фінансування спостерігалися у 2007 році (40,7 млн. грн.) та у 2010 році (72,6 млн. грн.). При загальному позитивному тренді неможливо не відзначити різкого падіння загального обсягу фінансування інноваційної діяльності у промисловості за останні п’ять років, що значно послаблює інноваційний потенціал регіону. Нестача фінансування інноваційної діяльності характерна для України в цілому, насамперед, через зменшення показника наукоємності ВВП, який знизився з 2011 року із $0,79 \%$ до $0,64 \%$ у 2015 році, та $є$ значно меншим середньоєвропейського показника, який складає близько 2 \%. За обсягом реалізованої інноваційної продукції станом на 2015 рік займає 9 місце серед областей України (табл. 2).

Динаміка показників інноваційної діяльності промисловості

Таблиця 2 Закарпатської області за 2005 - 2015 рр., од., тис. грн., \%*

\begin{tabular}{|c|c|c|c|c|c|c|c|c|c|c|c|}
\hline \multirow{2}{*}{ Показники } & \multicolumn{11}{|c|}{ Роки } \\
\hline & 2005 & 2006 & 2007 & 2008 & 2009 & 2010 & 2011 & 2012 & 2013 & 2014 & 2015 \\
\hline 1 & 2 & 3 & 4 & 5 & 6 & 7 & 8 & 9 & 10 & 11 & 12 \\
\hline $\begin{array}{l}\text { Кількість } \\
\text { підприсмств, що } \\
\text { впроваджували } \\
\text { інновації, од. } \\
\text { \% до загальної } \\
\text { кількості промислових } \\
\text { підприємств }\end{array}$ & $\begin{array}{l}16 \\
9,2\end{array}$ & $\begin{array}{l}28 \\
9,1\end{array}$ & $\begin{array}{l}23 \\
7,2\end{array}$ & $\begin{array}{c}26 \\
10,2\end{array}$ & $\begin{array}{l}24 \\
9,1\end{array}$ & $\begin{array}{l}23 \\
9,2\end{array}$ & $\begin{array}{l}13 \\
8,5\end{array}$ & $\begin{array}{l}14 \\
6,6\end{array}$ & $\begin{array}{l}12 \\
5,5\end{array}$ & $\begin{array}{l}12 \\
4,5\end{array}$ & $\begin{array}{l}11 \\
8,0\end{array}$ \\
\hline $\begin{array}{l}\text { Місце серед областей } \\
\text { України за кількістю } \\
\text { підприємств, що } \\
\text { впроваджували } \\
\text { інновації }\end{array}$ & 17 & 12 & 18 & 19 & 21 & 22 & 24 & 24 & 24 & 23 & 21 \\
\hline $\begin{array}{l}\text { Загальний обсяг } \\
\text { фінансування } \\
\text { інноваційної } \\
\text { діяльності, тис. грн. }\end{array}$ & 6031,5 & 14031,0 & 40702,7 & 14020,0 & 39317,3 & 72615,4 & 31336,6 & 32769,1 & 25026,7 & 16576,1 & 22530,6 \\
\hline $\begin{array}{c}\text { Місце серед областей } \\
\text { України за загальним } \\
\text { обсягом фінансування } \\
\text { інноваційної } \\
\text { діяльності }\end{array}$ & 23 & 23 & 21 & 24 & 23 & 17 & 24 & 23 & 22 & 23 & 21 \\
\hline $\begin{array}{l}\text { Освосно виробництво } \\
\text { інноваційних видів } \\
\text { продукції, } \\
\text { найменувань, од. }\end{array}$ & 33 & 34 & 54 & 22 & 11 & 16 & 14 & 11 & 20 & 8 & 9 \\
\hline
\end{tabular}




\begin{tabular}{|c|c|c|c|c|c|c|c|c|c|c|c|}
\hline \multicolumn{12}{|c|}{ Продовження табл. 2} \\
\hline 1 & 2 & 3 & 4 & 5 & 6 & 7 & 8 & 9 & 10 & 11 & 12 \\
\hline $\begin{array}{l}3 \text { них нових видів } \\
\text { техніки, од. }\end{array}$ & 2 & 8 & 4 & 4 & 3 & 1 & 2 & 1 & 6 & $\mathrm{X}$ & 1 \\
\hline $\begin{array}{l}\text { Обсяг реалізованої } \\
\text { інноваційної } \\
\text { продукції, тис. грн. / } \\
\text { \% до загального обсягу } \\
\text { реалізованої } \\
\text { промислової продукції }\end{array}$ & $\begin{array}{c}100270,1 \\
3,5\end{array}$ & $\begin{array}{c}153769,2 \\
3,6\end{array}$ & $\begin{array}{c}114722,1 \\
3,2\end{array}$ & $\begin{array}{c}151959,9 \\
2,3\end{array}$ & $\begin{array}{c}445416,4 \\
9,1\end{array}$ & $\begin{array}{c}878597,8 \\
14,4\end{array}$ & $\begin{array}{c}918513,8 \\
11,9\end{array}$ & $\begin{array}{c}1052479 \\
7 \\
13,4\end{array}$ & $\begin{array}{c}1363892,4 \\
15,5\end{array}$ & $\begin{array}{c}837562,5 \\
8,4\end{array}$ & $\begin{array}{c}583169,7 \\
4,6\end{array}$ \\
\hline $\begin{array}{l}\text { Місце серед областей } \\
\text { України за обсягом } \\
\text { реалізованої } \\
\text { інноваційної продукції }\end{array}$ & 20 & 19 & 21 & 21 & 14 & 10 & 10 & 9 & 8 & 9 & 9 \\
\hline $\begin{array}{l}\text { Обсяг реалізованої } \\
\text { інноваційної } \\
\text { продукції за межі } \\
\text { України, тис. грн. / \% } \\
\text { до загального обсягу } \\
\text { реалізованої } \\
\text { інноваційної продукції }\end{array}$ & $\begin{array}{c}79308,9 \\
79,1\end{array}$ & $\begin{array}{c}102381,1 \\
66,6\end{array}$ & $\begin{array}{c}85165,9 \\
74,2\end{array}$ & $\begin{array}{c}76139,7 \\
50,1\end{array}$ & $\begin{array}{c}391775,6 \\
88,0\end{array}$ & $\begin{array}{c}811953,3 \\
92,4\end{array}$ & $\begin{array}{c}863450,4 \\
94,0\end{array}$ & $\begin{array}{c}958065,3 \\
91,0\end{array}$ & $\begin{array}{c}364268,4 \\
26,7\end{array}$ & $\begin{array}{c}238363,8 \\
28,5\end{array}$ & $\begin{array}{c}424384,1 \\
72,8\end{array}$ \\
\hline
\end{tabular}

*Розробив автор, базуючись на [7-13]

Для покращення ситуації у сфері інновацій в області планується залучити значні обсяги інвестицій у промисловий сектор, зокрема через: індустріальний парк „Соломоново” (виробництво автомобілів, автокомпонентів та автокомплектуючих), який знаходиться в Ужгородському районі, передбачено залучити 7,0 млн. дол. США іноземних інвестицій; запланований індустріальний парк „Нарцис” (фармакологія, косметологія, харчові добавки та поглиблена переробка дикоростучих ягід) у Хустському районі.

У Закарпатській області діє Регіональна стратегія розвитку Закарпатської області на період до 2020 року, затверджена рішенням обласної ради 06.03.2015 № 1220 [17], де у розділі 5 „Стратегічні цілі та сценарії розвитку області до 2020 року” визначена ціль „Формування конкурентоспроможної та інноваційної економіки" через підтримку інноваційного підприємництва та економіки знань за допомогою підтримки інноваційної діяльності підприємств у регіоні, формування інституцій (у т.ч. мережевих) регіонального розвитку зі спрямуванням на інноваційне підприємництво та забезпечення ефективної співпраці учасників і організацій в ланцюжку „Освітанаука-інновації-підприємництво”. Дана ціль реалізується за допомогою Програми розвитку малого і середнього підприємництва в області на
2017 - 2018 роки, що затверджена рішенням обласної ради 22.12.2016 № 607 [18], де йдеться лише про сприяння розвитку інноваційних технологій у сфері малого підприємництва та зміцнення інноваційного потенціалу суб'єктів малого та середнього підприємництва. У ній передбачається: проведення моніторингу впровадження інвестиційно-інноваційних проектів, аналізу ефективності використання отриманих бюджетних коштів; організація засідань у форматі „круглих столів” щодо обговорення конкретних дій, формулювання запитів, розроблення та впровадження інновацій, що стосуються діяльності суб'єктів підприємництва; започаткування конкурсу „Кращий підприємець по впровадженню інноваційних технологій”.

Але 3 вищевикладеного випливає, що у сучасних ринкових умовах для розвитку інноваційної діяльності у Закарпатській області це $\epsilon$ явно недостатнім. Як і у всіх областей України, стратегічною метою розвитку області $є$ реалізація регіональної інноваційної політики, яка повинна формуватися місцевими органами влади у вигляді концепцій і регіональних програм інноваційного розвитку, які затверджуються обласними радами і реалізуються відповідними місцевими органами влади. Для цього в області $\epsilon$ всі передумови (табл. 3).

Таблиця 3

\section{Елементи інноваційної інфраструктури Закарпатської області*}

\begin{tabular}{|c|c|}
\hline Елемент & Характеристика \\
\hline $\begin{array}{c}\text { ТОВ Науковий парк } \\
\text { „Ужгородський } \\
\text { національний університет” }\end{array}$ & $\begin{array}{l}\text { Створений на базі ДВНЗ «УжНУ» на основі рішення Закарпатської облради } 21.03 .2013 \\
\text { № } 683 \text { „Про програму створення Наукового парку «УжНУ», який регіональною владою } \\
\text { визначений базовою організацією інноваційної інфраструктури регіону. } \\
\text { До основних функцій Наукового парку увійшли: створення нових видів інноваційних } \\
\text { продуктів; сприяння розвитку та підтримка малого інноваційного підприємництва; } \\
\text { підтримка науковоємного виробництва; розвиток міжнародного і вітчизняного } \\
\text { співробітництва у сферах науково-технічної та інноваційної діяльності, залучення } \\
\text { іноземних інвестицій. }\end{array}$ \\
\hline
\end{tabular}




\begin{tabular}{|c|c|}
\hline \multicolumn{2}{|r|}{ Продовження табл. 3} \\
\hline $\begin{array}{l}\text { Індустріальний парк } \\
\text { „Соломоново” }\end{array}$ & $\begin{array}{l}\text { Перший в Україні масштабний проект із створення високотехнологічного майданчика } \\
\text { автопромислового виробництва. Керуюча компанія „Сезпарксервіс” (група компаній } \\
\text { „Атолл Холдінг”). } \\
\text { Індустріальний парк „Соломоново” зареєстрований в Державному реєстрі індустріальних } \\
\text { парків України } 06.06 .2014 \text {, і як один } 3 \text { найбільш перспективних промислових } \\
\text { інвестиційних майданчиків, має ряд преференцій та державні гарантії, закріплені на } \\
\text { законодавчому рівні. }\end{array}$ \\
\hline $\begin{array}{c}\text { Відділ патентно- } \\
\text { ліцензійного забезпечення } \\
\text { та комерціалізації науково- } \\
\text { дослідної частини ДВНЗ } \\
\text { „УжНУ” }\end{array}$ & $\begin{array}{l}\text { На патентно-ліцензійний відділ НДЧ покладаються наступні функції: здійснення } \\
\text { методичного керівництва і допомоги авторам, участь у проведенні патентних досліджень } \\
\text { на всіх етапах виконання НДР; реалізація заходів правової охорони об'єктів } \\
\text { інтелектуальної власності, створених в результаті наукової діяльності шляхом: } \\
\text { оформлення і представлення в Держпатент України за участі авторів матеріалів і заявок на } \\
\text { відкриття, винаходи, корисні моделі, ведення переписки по них; забезпечення обліку } \\
\text { охоронних документів і звітності за результатами патентно-ліцензійної роботи, ії аналіз, } \\
\text { здійснення правової підтримки отриманих охоронних документів; оформлення і укладання } \\
\text { ліцензійних і інших передбачених законодавством угод на продаж і використання об'єктів } \\
\text { інтелектуальної власності (патентів на винаходи, корисні моделі); формування і } \\
\text { систематичне поповнення патентного фонду за основними напрямами наукової діяльності } \\
\text { університету і забезпечення широкого доступу до нього науково-педагогічних } \\
\text { працівників, студентів, аспірантв університету. }\end{array}$ \\
\hline $\begin{array}{c}\text { Центр інновацій та } \\
\text { розвитку ДВНЗ „УжНУ” }\end{array}$ & $\begin{array}{l}\text { Основними завданнями центру є: сприяння розвитку міжнародних, зокрема } \\
\text { транскордонних наукових контактів і спільних досліджень; участь у розробці та реалізації } \\
\text { міжнародних, загальнодержавних, регіональних, місцевих стратегій і програм розвитку; } \\
\text { складання проектів, включно міжнародних, спрямованих на впровадження результатів } \\
\text { прикладних досліджень, технологічних і аналітичних розробок у виробництво, } \\
\text { комерціалізацію науки. }\end{array}$ \\
\hline $\begin{array}{c}\text { Національний контактний } \\
\text { пункт програми Свросоюзу } \\
\text { HORIZON } 2020 \text { за } \\
\text { пріоритетними напрямами } \\
\text { „Харчова безпека, стале } \\
\text { сільське господарство, } \\
\text { морські дослідження та } \\
\text { біоекономіки” і „Здоров’я, } \\
\text { демографічні зміни та } \\
\text { добробут” на базі ДВНЗ } \\
\text { „УжНУ” }\end{array}$ & $\begin{array}{l}\text { Horizon } 2020 \text { - найбільша програма ЄС з дослідження та інновацій. Програма передбачає } \\
\text { фінансування наукових досліджень, інноваційних розробок з наступним упровадженням } \\
\text { на ринку. Фонд програми складає майже } 80 \text { мільярдів євро, фінансування передбачене на } \\
\text { семирічний період }(2014-2020) \text {. Horizon } 2020 \text { дозволяє реалізувати поставлені цілі } \\
\text { шляхом поєднання досліджень та інновацій і зосередження на трьох ключових аспектах: } \\
\text { передова наука, індустріальне лідерство та соціальні виклики. }\end{array}$ \\
\hline
\end{tabular}

*Розробив автор, базуючись на $[1 ; 2 ; 5 ; 16 ; 20]$

Використовуючи наявний інноваційний політики у сфері інновації, на основі кращих потенціал Закарпатської області, для практик регіонів в Україні, Закарпатській області ефективного п продовження здійснюваної запропоновано вжити ряд заходів (табл. 4).

Таблиця 4

\section{Першочергові заходи Закарпатської обласної державної адміністрації для стимулювання інноваційної складової області*}

\begin{tabular}{|c|c|}
\hline Заходи & Завдання \\
\hline 1 & 2 \\
\hline $\begin{array}{l}\text { Розробити проект Програми розвитку науково-тех- } \\
\text { нічної та інноваційної діяльності області до } 2020 \\
\text { року згідно з методичними рекомендаціями щодо } \\
\text { розроблення середньострокових пріоритетних } \\
\text { напрямів інноваційної діяльності галузевого та } \\
\text { регіонального рівня, загальними рекомендаціями } \\
\text { щодо розроблення регіональних програм } \\
\text { інноваційного розвитку, Законом України „Про } \\
\text { інноваційну діяльність”, а також відповідно до } \\
\text { Регіональної стратегія розвитку Закарпатської } \\
\text { області на період до 2020 року, затвердженої } \\
\text { рішенням обласної ради } 06.03 .2015 \text { № 2012. }\end{array}$ & $\begin{array}{l}\text { 1. Запровадження програмно-цільового принципу } \\
\text { управління інноваційною діяльністю в регіоні } \\
\text { відповідними наслідками для фінансування інноваційної } \\
\text { діяльності. } \\
\text { 2. Визначення та реалізація пріоритетних напрямів } \\
\text { інноваційної діяльності. } \\
\text { 3. Створення та розвиток нових елементів інноваційної } \\
\text { інфраструктури шляхом покращення системи } \\
\text { інформаційного забезпечення інноваційної діяльності. } \\
\text { 4. Просування інноваційної культури шляхом залучення } \\
\text { максимально широкої аудиторії. }\end{array}$ \\
\hline
\end{tabular}




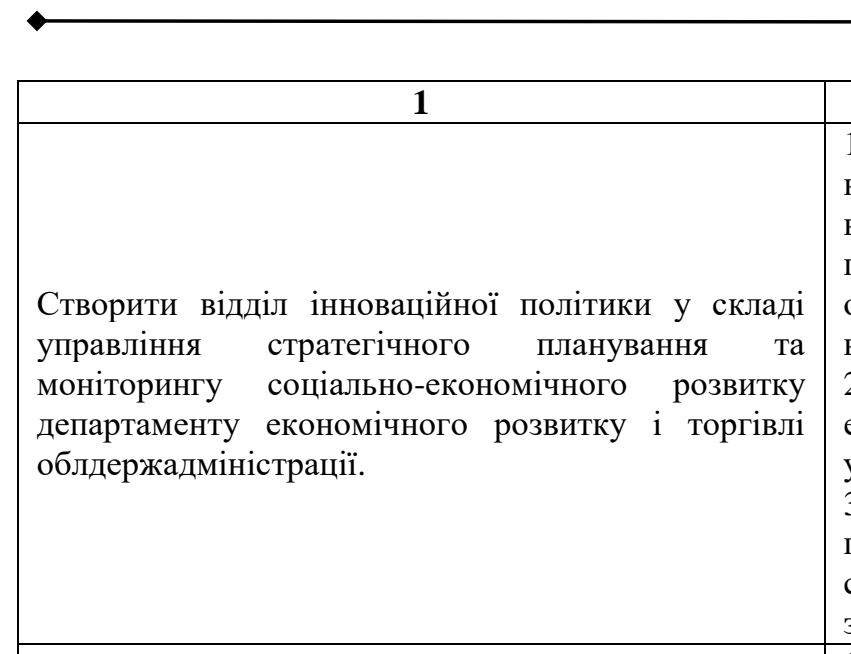

Продовження табл. 4

1. Забезпечення реалізації державної промислової та науково-технічної політики в галузях: машинобудування; виробництві хімічних речовин і хімічної продукції; легкій промисловості (текстильне виробництво, виробництво одягу, шкіри, виробів зі шкіри та інших матеріалів); виготовленні виробів з деревини.

2. Здійснення організаційних заходів щодо підвищення ефективності діяльності підприємств промисловості та установ галузевої науки;

3. Здійснення в межах компетенції управління підприємствами у відповідних галузях, що передані до сфери управління обласної державної адміністрації, згідно з чинним законодавством.

1. Всебічне сприяння прискоренню науково-технічного прогресу, піднесення ролі вітчизняної науки і техніки у якісному перетворенні продуктивних сил.

2. Сприяння переводу економіки регіону на інноваційну модель розвитку.

3. Розробка та вжиття заходів щодо підвищення ефективності і конкурентоспроможності виробництва та створення за новими технологіями сфери послуг.

Створити Регіональну раду 3 питань наукової, науково-технічної та інноваційної діяльності як консультативно-дорадчий орган при облдержадміністрації, до складу якого мали б ввійти представники територіальних органів центральних органів виконавчої влади, місцевих органів виконавчої влади, представники підприємств, організацій, академічних i галузевих наукових установ, вищих навчальних закладів, а також установ Національної академії наук України.

4. Посилення орієнтації науково-технічного розвитку на вирішення соціальних проблем, що створює умови для найбільш повної реалізації державної регіональної політики та задовольняє вимоги соціальної, екологічної, енергетичної, економічної та технологічної безпеки держави.

5. Розвиток інноваційної культури, створення в суспільстві атмосфери конструктивного відношення до нових ідей, нововведень.

6. Сприяння підприємствам в освоєнні ринків технологій.

7. Створення умов для функціонування позабюджетних джерел фінансування науково-дослідних та дослідноконструкторських робіт.

8. Поліпшення економічних, правових та організаційних умов діяльності інвесторів.

9. Сприяння вдосконаленню забезпечення промисловості висококваліфікованими кадрами.

Утворити Комісію 3 питань інтелектуальної власності як консультативно-дорадчий орган при облдержадміністрації.

Забезпечення запобігання незаконному використанню наукоємної товарної продукції, виробництву та реалізації контрафактних товарів i послуг, складовими яких $\epsilon$ науково-технічні розробки і об'єкти права інтелектуальної власності.

На офіційному сайті облдержадміністрації створити розділ „Інноваційна діяльність”

Надання широкого доступу громадськості до обговорення питань, пов'язаних $з$ реалізацією інноваційної політики в регіоні.

*Розробив автор

Використання наявної інноваційної інфраструктури і реалізація даних пропозицій дозволить здійснити подальший поштовх інноваційного розвитку регіону та отримати економічну вигоду в майбутньому.

Висновки i перспективи подальших досліджень. У Закарпатській області кількість підприємств та організацій, що займалися виконанням наукових та науково-технічний робіт за досліджуваний період 2005 - 2015 рр., скоротилась більш ніж у двічі. Загальний обсяг фінансування внутрішніх витрат на виконання наукових та науково-технічних робіт власними силами наукових організацій у 2015 зріс більш ніж у 2,5 рази порівняно 32005 роком. За аналізований період, кількість підприємств, що займались інноваційною діяльністю зменшилась майже у 2 рази. Обсяг реалізованої інноваційної продукції склав 583,2 млн. грн., 3 якої 72,8 \% реалізовано за межі України та даний тренд простежується протягом майже всього досліджуваного періоду. 
3'ясовано та надано характеристику елементам інноваційної інфраструктури області, надано пропозиції місцевому органу виконавчої влади щодо подальшого розвитку інноваційної діяльності в регіоні.
Перспективним напрямом дослідження залишається моніторинг функціонування елементів інноваційної інфраструктури, аналіз їх впливу на економіку регіону, що мають забезпечувати прискорення впровадження у виробництво останніх досягнень науки і техніки.

\section{ПЕРЕЛІК ВИКОРИСТАНИХ ДЖЕРЕЛ}

1. HORIZON 2020 [Електронний ресурс] - Режим доступу до pecypcy: http://ncp-uzhnu.net.ua/?page_id=30.

2. Відділ патентно-ліцензійного забезпечення та комерціалізації [Електронний ресурс] - Режим доступу до pecypcy: http://www.uzhnu.edu.ua/uk/cat/ndch-dep_patent.

3. Грицаєнко М. І. Сутність та склад інноваційного потенціалу регіону / М. І. Грицаєнко. // Економіка розвитку. - 2013. - №4. - С. 52-57.

4. Інвестиційні процеси в промисловості України / [В. Г. Федоренко, О. Ф. Іткін, Д. В. Степанов та ін.]. - К.: Наук. світ, 2001. -447 с.

5. Індустріальний парк „Соломоново” [Електронний ресурс] - Режим доступу до ресурсу: http://www.sezparkservice.com/sps_ua/.

6. Наукова та інноваційна діяльність області у 2015 році. Статистичний збірник // [Відпов. за випуск Л.Б. Антошик]. - К.: Головне управління статистики у Закарпатській області, 2016. - С. 112.

7. Наукова та інноваційна діяльність України у 2009 році. Статистичний збірник // [Відпов. за випуск I.В. Калачова]. - К.: ДП „Інформаційно-видавничий центр Держкомстату України”, 2010. - С. 347.

8. Наукова та інноваційна діяльність України у 2010 році. Статистичний збірник // [Відпов. за випуск I.В. Калачова]. - К.: ДП „Інформаційно-видавничий центр Держкомстату України”, 2011. - С. 282.

9. Наукова та інноваційна діяльність України у 2011 році. Статистичний збірник // [Відпов. за випуск I.В. Калачова]. - К.: ДП „Інформаційно-видавничий центр Держкомстату України”, 2012. - С. 305.

10. Наукова та інноваційна діяльність України у 2012 році. Статистичний збірник // [Відпов. за випуск I.В. Калачова]. - К.: ДП „Інформаційно-видавничий центр Держкомстату України”, 2013. - С. 287.

11. Наукова та інноваційна діяльність України у 2013 році. Статистичний збірник // [Відпов. за випуск О.О. Кармазіна]. - К.: ДП „Інформаційно-видавничий центр Держкомстату України”, 2014. - С. 314.

12. Наукова та інноваційна діяльність України у 2014 році. Статистичний збірник // [Відпов. за випуск О.О. Кармазіна]. - К.: ДП „Інформаційно-видавничий центр Держкомстату України”, 2015. - С. 255.

13. Наукова та інноваційна діяльність України у 2015 році. Статистичний збірник // [Відпов. за випуск О.О. Кармазіна]. - К.: ДП „Інформаційно-видавничий центр Держкомстату України”, 2016. - С. 257.

14. Науковці Ужгородського національного та Кошицького технічного університетів домовилися формувати „Українсько-словацький міжнародний центр інновацій і трансферу технологій” [Електронний ресурс] - Режим доступу до ресурсу: http://www.uzhnu.edu.ua/uk/news/naukovtsi-uzhgorodskogo-ta-koshitskogo-universitetivdomovilisya.htm.

15. Пилясов А. Н. Оценка творческого потенциала российских региональных сообществ / А. Н. Пилясов, О. В. Колесникова. // Вопросы экономики. - 2008. - №9. - С. 50-69.

16. Рішення Закарпатської обласної ради 21.03.2013 № 683 „Про програму створення Наукового парку „Ужгородський національний університет” [Електронний ресурс] - Режим доступу до pecypcy: http://zakarpatrada.gov.ua/normatyvni-dokumenty/rishennya-rady/vi-sklykannya/13-sesiya-21-03-2013/.

17. Рішення Закарпатської обласної ради 06.03.2015 № 1220 „Про Регіональну стратегію розвитку Закарпатської області на період до 2020 року" [Електронний ресурс] - Режим доступу до ресурсу: http://zakarpat-rada.gov.ua/normatyvni-dokumenty/rishennya-rady/vi-sklykannya/21-sesiya-06-03-2015/.

18. Рішенням Закарпатської обласної ради 22.12.2016 № 607 „Про Програму розвитку малого і середнього підприємництва в області на 2017 - 2018 роки” [Електронний ресурс] - Режим доступу до ресурсу: http://zakarpat-rada.gov.ua/normatyvni-dokumenty/rishennya-rady/vii-sklykannya/5-sesiya-iii-zasidannya-07-12-2016/.

19. Федулова Л. І. Напрями розвитку індустріальних парків щодо реалізації інноваційного потенціалу регіонів України / Л. І. Федулова. // Економічні інновації: Зб. наук. праць. - 2013. - №53. - С. 296-305.

20. Центр інновацій та розвитку [Електронний ресурс] - Режим доступу до ресурсу: http://www.uzhnu.edu.ua/uk/cat/deps-ndc_innov_rozv.

\section{REFERENCES}

1. HORIZON 2020 [HORIZON 2020]. (n.d.). ncp-uzhnu.net.ua. Retrived from: http://ncpuzhnu.net.ua/?page_id=30 [in Ukrainian].

2. Viddil patentno-litsenziinoho zabezpechennia ta komertsializatsii [Department of Patent and Licensing Providing and Commercialization]. (n.d.). uzhnu.edu.ua. Retrived from: http://www.uzhnu.edu.ua/uk/cat/ndchdep_patent [in Ukrainian]. 
3. Hrytsaienko, M.I. (2013). Sutnist ta sklad innovatsiinoho potentsialu rehionu [The essence and composition of the innovation potential of the region]. Ekonomika rozvytku [Development economics], 4, 52-57 [in Ukrainian].

4. Fedorenko, V.H., Itkin, O.F., Stepanov, D.V. (2001). Investytsiini protsesy v promyslovosti Ukrainy [Investment processes in the industry of Ukraine]. Naukovyi svit, Kyiv [in Ukrainian].

5. Industrialnyi park „Solomonovo” [Solomonovo industrial park]. (n.d.). sezparkservice.com. Retrived from: http://www.sezparkservice.com/sps_ua/ [in Ukrainian].

6. Naukova ta innovatsiina diialnist oblasti u 2015 rotsi. Statystychnyi zbirnyk [Research and innovation activity in region in 2015. Statistical yearbook], Uzhgorod: Holovne upravlinnia statystyky u Zakarpatskii oblasti [in Ukrainian].

7. Naukova ta innovatsiina diialnist Ukrainy u 2009 rotsi. Statystychnyi zbirnyk [Research and innovation activity in Ukraine in 2009. Statistical yearbook], Kyiv: DP „Informatsiino-vydavnychyi tsentr Derzhkomstatu Ukrainy” [in Ukrainian].

8. Naukova ta innovatsiina diialnist Ukrainy u 2010 rotsi. Statystychnyi zbirnyk [Research and innovation activity in Ukraine in 2010. Statistical yearbook], Kyiv: DP „Informatsiino-vydavnychyi tsentr Derzhkomstatu Ukrainy” [in Ukrainian].

9. Naukova ta innovatsiina diialnist Ukrainy u 2011 rotsi. Statystychnyi zbirnyk [Research and innovation activity in Ukraine in 2011. Statistical yearbook], Kyiv: DP „Informatsiino-vydavnychyi tsentr Derzhkomstatu Ukrainy” [in Ukrainian].

10. Naukova ta innovatsiina diialnist Ukrainy u 2012 rotsi. Statystychnyi zbirnyk [Research and innovation activity in Ukraine in 2012. Statistical yearbook], Kyiv: DP „Informatsiino-vydavnychyi tsentr Derzhkomstatu Ukrainy” [in Ukrainian].

11. Naukova ta innovatsiina diialnist Ukrainy u 2013 rotsi. Statystychnyi zbirnyk [Research and innovation activity in Ukraine in 2013. Statistical yearbook], Kyiv: DP „Informatsiino-vydavnychyi tsentr Derzhkomstatu Ukrainy” [in Ukrainian].

12. Naukova ta innovatsiina diialnist Ukrainy u 2014 rotsi. Statystychnyi zbirnyk [Research and innovation activity in Ukraine in 2014. Statistical yearbook], Kyiv: DP „Informatsiino-vydavnychyi tsentr Derzhkomstatu Ukrainy” [in Ukrainian].

13. Naukova ta innovatsiina diialnist Ukrainy u 2015 rotsi. Statystychnyi zbirnyk [Research and innovation activity in Ukraine in 2015. Statistical yearbook], Kyiv: DP „Informatsiino-vydavnychyi tsentr Derzhkomstatu Ukrainy” [in Ukrainian].

14. Naukovtsi Uzhgorodskoho natsionalnoho ta Koshytskoho tekhnichnoho universytetiv domovylysia formuvatu „Ukrainsko-slovatskyi mizhnarodnyi tsentr innovatsii I transferu tekhnolohii” [Scientists of Uzhgorod National University and Košice Technical University agreed to form the „Ukrainian-Slovak international center for innovations and technology transfer"]. (n.d.). uzhnu.edu.ua. Retrived from: http://www.uzhnu.edu.ua/uk/news/naukovtsiuzhgorodskogo-ta-koshitskogo-universitetiv-domovilisya.htm [in Ukrainian].

15. Piliasov, A.N., Koliesnikova, O.V. (2008). Otsienka tvorchieskogo potientsiala rossiiskikh riegionalnykh soobshchiestv [Assessment of the creative potential of russian regional communities]. Voprosy ekonomiki [Issues of economics], 9, 50-69 [in Russian].

16. Rishennia Zakarpatskoi oblasnoi rady 21.03.2013 № 683 „Pro prohramu stvorennia Naukovoho parku „Uzhgorodskyi natsionalnyi universytet” [Decision of the Transcarpathian Regional Council of March 21, 2013 No. 683 „About the Program of creation of Science Park Uzhgorod National University”]. (n.d.). zakarpat-rada.gov.ua. Retrived from: http://zakarpat-rada.gov.ua/normatyvni-dokumenty/rishennya-rady/vi-sklykannya/13-sesiya-21-032013/ [in Ukrainian].

17. Rishennia Zakarpatskoi oblasnoi rady 06.03.2015 № 1220 „Pro Rehionalnu stratehiiu rozvytku Zakarpatskoi oblasti na period do 2020 roku [Decision of the Transcarpathian Regional Council dated March 6, 2015 No. 1220 „The Regional Strategy for the Development of the Transcarpathian Region until 2020"]. (n.d.). zakarpat-rada.gov.ua. Retrived from: http://zakarpat-rada.gov.ua/normatyvni-dokumenty/rishennya-rady/vi-sklykannya/21-sesiya-06-032015/ [in Ukrainian].

18. Rishennia Zakarpatskoi oblasnoi rady 22.12.2016 № 607 „Pro Prohramu rozvytku maloho i serednoho pidpryiemnytstva v oblasti na 2017 - 2018 roky" [Decision of the Transcarpathian Regional Council dated December 22, 2011 No. 607 „About the Program of development of small and medium enterprises in the region for 2017-2018"]. (n.d.). zakarpat-rada.gov.ua. Retrived from: http://zakarpat-rada.gov.ua/normatyvni-dokumenty/rishennya-rady/viisklykannya/5-sesiya-iii-zasidannya-07-12-2016/ [in Ukrainian].

19. Fedulova, L.I. (2013). Napriamy rozvytku industrialnykh parkiv shchodo realizatsii innovatsiinoho potentsialu rehioniv Ukrainy [Directions of development of industrial parks in relation to realization of innovative potential of regions of Ukraine]. Ekonomichni innovatsii [Economic innovation], 53, 296-305 [in Ukrainian].

20. Tsentr innovatsii ta rozvytku [Centre of innovation and development]. (n.d.). uzhnu.edu.ua. Retrived from: http://www.uzhnu.edu.ua/uk/cat/deps-ndc_innov_rozv [in Ukrainian].

Одержано 11.09.2017 p. 